\title{
THE SOCIAL IMPACT OF PETRONAS OIL COMPANY ON THE ASPECT OF EDUCATION IN AL GARRAF OIL FIELD IN DHIQAR PROVINCE
}

\author{
Ahmed Mohsen Juda ${ }^{1}$, Abdul Rahim Ahmad ${ }^{1}$, Mohammed Sabri Haron ${ }^{1}$
}

${ }^{1}$ Institute of Malaysian and International Studies (IKMAS) - Politics and International Relations Department

National University of Malaysia (UKM)

\begin{abstract}
As a matter of fact, the existence of the oil fields and the work of the oil companies in the residential areas have an impact on the style and standard of living of the local communities and the consequential change in society. The problem, in this research, represents the big rise in the illiteracy rate, the falling level of education and the high unemployment rate in the local communities that are found in Al Gharraf oil field. The most important objectives of the research is to identify the main methods and procedures carried out by Petronas which help the local communities in Al Garraf oil field so as to ensure the development of their skills through learning and building of their own abilities through the establishment of $\mathrm{Al}$ Gharraf vocational training center. The study adopts the analytical descriptive approach by identifying the problem and find out the impact of Petronas which is subjected to the analysis by the interview and the questionnaire form .They were distributed in the study area.The most important results that have been reached that the presence of Petronas and the establishment of Al Gharraf vocational training center have a positive impact on the development of people skills to ensure that they are qualified for work in Petronas Company or its members or the rehabilitation and education of individuals toward getting a certain craft and helping to start a particular work.
\end{abstract}

KEYWORDS: Social impact, Petronas, Al Garraf field, the education aspect, Dhiqar.

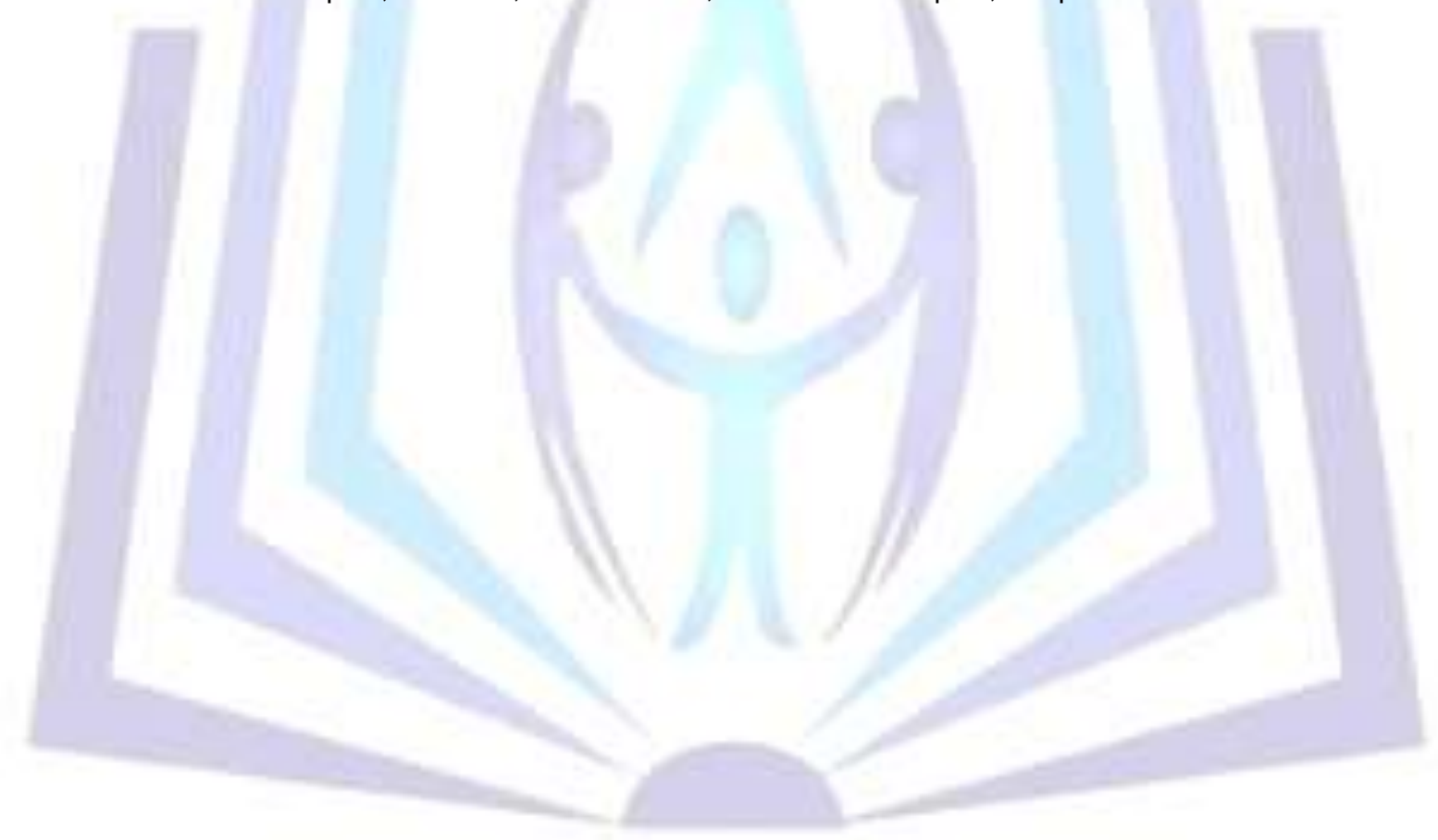

\section{Council for Innovative Research}

Peer Review Research Publishing System

Journal: International Journal Of Management \& Information Technology

Vol. 10, No 8

editorsijmit@gmail.com

www.ijmit.com 


\section{INTRODUCTION}

The social aspects, and what is involved in the impact of the changing of society, require a focus in its study and to give it a special significance, particularly the population or agricultural areas where there is oil. It is noticeable that most of the studies and books that have been studied did not give the proper space of themes and discussed the social aspects, but the focus was on the economic and political aspects of the impact of oil on society, for example,the study made by Stinfz [1], which dealt with the first beginnings of the oil discoveries in the Arab region, and the keenness of the oil companies that determine oil prices are on their own and in their favor, and was a strange phenomenon in economic history that the buyer determines the price of the goods he wants to buy them. We note that the writer focused heavily on the role of international oil companies in the change in oil prices according to their interests and their role in the economic and political change for people and the linking of events with the events of Gulf war. He did not give the role to the impact of oil on the social aspects that can play in the process of social change for population . The study that is carried out by Primakov [2], which he addressed the economic issues and its close relationship with means and the new forms of oil companies relations in the oil producing countries which are usually not fixed, but constantly shifting as a result of the pursuit of these companies to increase profits and install these sources of profits and the emergence of real relationships which arose after the nationalization movement between the three parties: the OPEC countries, monopolies of oil, the advanced capitalist countries oil-consuming because of the oil factor. The writer focused on the development of economic ties for oil companies and they changed according to the earnings and oil prices, he did not address the social relations and the influential role oil in its composition, evolution and development .It is reflected positively on the corporation profits. Majeed [3], dealt with the impact of the increasing in the oil prices on the economic growth and the importance of oil in the Middle East and Iraq to meet the needs of the world's oil, especially big producers such as Iraq, Saudi Arabia, and Iran. They looked at oil as a strategy commodity that is governed by external conditions beyond the supply and demand for political reasons, and they are almost monopolistic to the big global companies. We noted that the writer focused on the political role of oil and what it played in the achievement of the process of change, especially Iraq because of what is owned by a large reserve without a stand on the social aspect which has a significant role in the process role economic and political change in Iraq.

Saddam [4], dealt with the geo-strategic aspects of the oil fields in Kirkuk, politically, and economically, and the resulting disclosure of the conflict between local interests, regional, and international, on Kirkuk oil since its discovery until now especially after the second Gulf War on Iraq, the events of 2003 and their impact on politics and the Iraqi economy and what is happening from a struggle for the province's oil and wealth between the central government in Baghdad and the Kurdistan region of Iraq because of oil.As mentioned in the above ,we noted that the writer focused on the political side for only one region in Iraq which is Kirkuk, without addressing the other areas in Iraq which is just as important as Kirkuk and stressed the impact of the oil at the local, international and regional levels without standing on the other social aspects in which oil plays a big role in it.

Ali [5], said that the Gulf War was to a large extent for oil. The researcher dealt with an essay for the writer Robert Kaplan, "The Gulf War was largely for oil", who is a senior analyst at Stratfor Algioboltakyin Foundation, a global intelligence company, the writer explained that the oil is a key factor in all Western military approach in the Middle East is plain to the point of making any controversy arises around, it seems as a marginal and influential thought. He gave an evidence of this ,the speech of the General John Abu Zeid US Central Command the former in Iraq by saying, "Sure, that the war in Iraq was for oil and we cannot deny it, and the words of US Secretary of Defense the current Chuck Hagel said, "People say that we do not fight Iraq for oil, of course we do it, and added Alan Greenspan, the former Chairman of the Federal Reserve as saying:" I am saddened that it is politically appropriate recognition of what everyone knows, which is that the Iraq war is largely was for oil, ".As mentioned in the above, we noted that the writer has focused on the second Gulf war on Iraq and its causes and the role of oil in this war ,he did not go into other aspects that could be the reason why the Gulf War occurred in Iraq, including the social factors and the change of the Iraqi community in accordance with the goals and interests of the United States that is seeking to achieve in Iraq in line with the direct and control on oil.

Therefore, the present study worked on to show and find out the social impact of the oil on the areas where there is oil and in particular areas with populations through several of the most important topics. Knowledge of the factors helping to develop and operate Al Gharraf field by Petronas and the statement of the company the most important achievements made by Petronas in the education sector and of Gharraf vocational training center (GVTC) .The objective of the establishment of Al Gharraf center for vocational training and the knowledge of the most important courses and their trainees that are graduated from the center and to clarify the positive and social impact to Al Garraf center for vocational training on the local communities and see the negative aspects of the center and to clarify the role of Petronas to develop Iraqi staffs and to clarify the negative aspects of the sessions held by Petronas. After the illustration of the theoretical framework for the study, which prepares the ground for the problem of the study show the field side that represents the field work done by the researcher and reached through the questionnaire form which was distributed to the study area to see the effect the Malaysian oil company Petronas on the educational side and the operation of labor in local communities. 


\section{THE MOST IMPORTANT FACTORS WHICH HELP TO DEVELOP AL GHARRAF OIL FIELD}

There are factors that have helped to develop Al Garraf ${ }^{1}$ oil field of the human and natural side the most important side is the natural side to the province of Dhiqar, including: The geological formations to Dhiqar province that is dating back to the geological ages and epochs of modern configuration. One of the main characteristics of the rocks in these deposits is that they are a few rock hardness that help to change their characteristics in terms of its ability to change easily and then facilitates the creation of projects such as the construction of transport routes and the excavating of the irrigation and drainage channels [6]. As well as the horizontal expansion in the Garraf oil field, and the possibility of setting up various projects at the present and in the future.

The main characteristics of the surface of Dhi Qar province is the existence of three sections, namely Al Sahal Al Rusubi, Western Plateau, marshes, they helped significantly to work and develop Al Garraf oil field. Where it holds an area of $11,500 \mathrm{~km}$ which represents $89 \%$ of the total area of the governorate and it is characterized by the low level of its ground that decline gradually, from $9.5 \mathrm{~m}$ above sea level in the northern part to $3.6 \mathrm{~m}$ in the center of the province when the city of Nasiriyah and continue this decline until it reaches $2-3 \mathrm{~m}$ below sea level at the Marshes of Chabaish and Al Hamar [7].

\section{The most important achievements made by Petronas in the education sector}

\subsection{Al Gharraf vocational training center (GVTC)}

On 14 / February / 2012 the contract was signed to build Gharraf vocational training center between both of the Deputy Governor Mr. Haider Binyan of the local government, Mr. Ambassador of Japan Susumu Hajisawa, Mr. Ikhlas Abdul Rahman, General Director of Petronas in Iraq and Mr. Katsuo Suzuki Vice President JAPEX [8]. According to the work program, that includes the Japanese government the construction and purchase of the necessary equipment to Al Gharraf vocational training center through a grant to the Iraqi government. In addition, each of Malaysia's Petronas and JAPEX Japanese company in the financing of the operation and maintenance of the center. It is managed by the Institute of Services for Relief and the Millennium Development Organization (MADS) Millennium Relief and Development [9].

The land that has been the vocational training center built (GVTC). As well as the land on which the football playing field has been building to Mr. Ma'arj Jassim Sahar [10] aged-old 60 years old who is considered as the first donor to this development project in the region which has Al Garraf oil field, who is currently working on as a watchman in the vocational training center (GVTC). There are several departments in Al Gharraf Vocational Training Institute (GVTC):

\section{English Department. \\ 2. Department of Computing. \\ 3. Cooling and Adapt Department \\ 4. Sewing department. \\ 5. Cosmetic Department \\ 6. Department of teaching methods. \\ 7. Electricity basics department. \\ 8. IT department.}

These departments include men and women, but some departments have a privacy either prepared for the work by males only or women such as sewing department or the private cosmetic women only department as well as there are special department for men only such as cooling and adjustment department. In addition to the attendance of some department of the joint work between men and women such as the Department of Computing , the Department of English and teaching methods.

The objective of the establishment of Al Gharraf vocational training center (GVTC). The main objective of to create Al Gharraf center is represented by several points, and perhaps the most important, according to what said by those who are responsible for the center and those in charge of operation and preparation at present, the general supervisor of Mr. Yas Khudair, and the Assistant General Supervisor Mr. Salah Nasser [11].

1. To assist communities in Al Garraf oil field so as to ensure the development of their skills through learning and building their own abilities.

\footnotetext{
${ }^{1} \mathrm{Al}$ Garraf oil field is located within the administrative borders of the province of Dhi qar in southern part of Iraq and extends into three zones, namely the Al Rifai, district and Sugar Castle, and Al Fajar district. On the distance of $80 \mathrm{~km}$ north of Dhi qar. The total area of the field is up to $350 \mathrm{~km} 2$ oil reserves to almost 7 billion barrels of oil field, the current number of wells that is subject to work is 15 wells and the number of future wells is 277 wells between injection and production. Interview with Mr. Starr Jabara the manager of Al Garraf development oil field on 09.22.2014. Authorized publication.
} 
2. Learning toward the development of skills of individuals to ensure they qualify for work within the companies within Al Garraf oil field, and this does not mean that ensure you get the opportunity to work and it means precisely the rehabilitation of the person to be appropriate for the chance to work.

3. learning towards getting a certain craft and helping to start a particular business which is one of the important objectives, but as it turns out that the main aim behind the establishment of the center is as follows: -

A. The significant rise in the rate of illiteracy and the fall in the educational level in the local communities in Al Garraf oil field.

B. The high unemployment in these communities and the establishment of the center is working to decrease the unemployment by creating jobs fit their skills including mental and scientific aptitudes.

C.The high population density in these communities and the most important of these reasons is their relying on agriculture, so that the existence of the center including offers and diversity of the experiences that gives the ability to work.

D.The main courses and preparation that graduated from Al Gharraf vocational training center (GVTC) .On 17 / July / 2012.It has been opened Al Gharraf center for vocational training and formal to receive students who want to join these courses and then selected 44 advanced [12] to join the English language course and the courses of Information Technology (IT) that lasts for a month by the supervising Committee in the selection of applicants and the selection of applicants as clarified for the researcher occur in a good process and away from bias and favoritism through a written examination and oral interview to applicants who are selected through a competition among applicants. The reason in the choice of this method is due to a large number of competitors and the inability of the center to afford this huge number, in addition to the lack of teaching staff in the institute. In September of the same year, Al Gharraf center received 40 trainees who were distributed in two main sessions. The basics of electrical wiring and maintenance of air conditioners and cooling as well as the registration of 72 lady in the same month for access to the basics courses in sewing and courses of Information Technology (IT). The main courses held in 2013 are as in Table (1) shown below, where the total of trainees since 2012 to 2013 from communities 560 trainees [13] on various disciplines.

Table 1. Represents sessions held by Petronas, subject and duration.

\begin{tabular}{lll}
\hline Date & Session subject & Duration of the course \\
\hline 13 / January / 2013 & $\begin{array}{l}\text { The principles of English language and } \\
\text { Principles of information technology }\end{array}$ & one month \\
17 / February / 2013 & $\begin{array}{l}\text { The basics of electrical wiring and } \\
\text { the principles of the English language }\end{array}$ & one month \\
24/March / 2013 & the principles of the English language & one month \\
25 / March / 2013 & Basic principles of sewing for ladies only one month \\
31 / March / 2013 & principles of the women's beauty care & one month \\
\hline
\end{tabular}

The center's work does not concentrate on the local communities but also extended to include many of the other Petronas sectors. It has witnessed many new courses as:

1. From 5 to 29 / May / 2013 was the opening course for the staff of the South Oil Company in English for low intermediate level their number was 16 participants.

2. On 22 / April / 2013 was the opening course for the police staff of the protection force of oil in English language at the beginner level their number was 20 participants [14].

\section{THE SOCIAL IMPACT TO AL GHARRAF CENTER FOR VOCATIONAL TRAINING ON THE LOCAL COMMUNITIES (THE POSITIVE ASPECTS)}

It is clear from the abovementioned, the researcher through his fieldwork that the role of Al Garraf vocational training center is influential and has a social and psychological impact on the local communities through a number of things.

1. The unemployment. The work on the removal of unemployment through various means, directly or indirectly, to provide job opportunities to those who have been graduated by the center in Al Garraf oil field and take advantage of them through the skills and experience gained by them, knowing that those who have been trained by the Center in 2013 about 
560 trainees on various disciplines, and It should be noted that more than $23 \%$ found a job within six months of graduation.

2. The society.it has been through the center providing the local communities with the skills and abilities that were not exist before, but because of the existence of the center in making them able to serve themselves and their communities.

3. Women. The large and influential participation by women and unexpected in the overall domains that are either in the center through its participation in the courses or by the direct action in Al Garraf oil field as the center is considered the basic motive to women to enter the work and the participation of men in all the existing business. In addition, the development and creation of discoveries that are not found before in these communities such as cosmetic learning, and the principles of information technology, and technical information for the computers, and the principles of the English language, as it is also known as a simple communities did not have the means of progress and development to be able to keep up with the progress and development and renewal at various levels through the periods of time.

4. Malaysian Petronas company. the program that is established by Petronas to the Institute on the grounds that they are the funder and the operator to the center, it is one of the best types of vocational education and within the international standards. Which has helped significantly to achieve several things for the benefit of the local communities?

A. Curricula and books. The program which was prepared by Petronas assist dramatically in learning, through the speed of learning and gain experiences in these communities by the existence of the best curricula and books that help in learning.

B. Teaching staff. The selection of the teaching staff by Petronas helped on the implementation of the program which was prepared by the company and successfully acknowledged by society through the selection of efficient staffs that have sufficient experience and expertise to the local communities in those areas.

C. Capabilities. The presence of large possibilities whether physical or scientific to the company by Petronas on the implementation of plans and programs which had been prepared successfully to the center.

D. Credibility. One of the important factors for the implementation of the various programs is the credibility in dealing with others and implant the spirit of one team, and this is what characterized by Petronas through its dealings with the staff of the center or trainees.

e. Follow-up. The visits to the officials and the direct supervision by Petronas in the implementation of plans and programs designed to the center speed up to implement and achieve the goals that the Center created for.

\section{THE NEGATIVE EFFECTS ON AL GHARRAF CENTER FOR VOCATIONAL TRAINING ASPECTS}

Despite the importance of Al Gharraf vocational training center and its big role in the local communities, but there are some negative aspects which should be stand on and find solutions to them for the integration in work and the success of the project and the achievement of its objectives that it was established for as it seems to the researcher that the most important is the lack of teaching staff: to get acquainted with the nature of the work being done by the center and its services to the local communities ,the center needs to increase in the number of teaching staff as there is only two courses and this is not enough. When we asked the Director [15] of the Center for number Is it enough stated that, in the case of new courses and with large numbers where contracting with other teaching staff outside the center, this is part of the solution but it is not the required level as the center and what is required is to achieve many goals that needs increase in the number of teaching staff to be able to achieve the desired aims.

Location Capacity: The place where the sessions are held in Al Gharraf center is a very small, it does not afford the numbers that the center hopes to submit courses for them whether at present or future, as the one-room capacity in a normal situation, permits only 25 trainees and the total number of the halls in the Center are five classrooms with a wide lounge and a store with health attachments. The question here is how it hopes to achieve the purpose and performs its goals .The number the communities surrounding it are at least 100,000 people, in addition, it offers courses not only to these communities, but also to other beneficiaries. It has to be expanded to accommodate the coming numbers and to achieve the purpose for which it is established.

The quality of courses and trainees: As it is well known that learning takes time and follow-up in order to get the desired benefit from it and achieve the desired purpose. It has also been addressed in the research that courses ranging from 20-30 days and this time is not enough to the session, especially if we know that this communities are simple in their educational ability, and in acquiring skills quickly because they are mostly illiterate and few of them know how to read and write because of the political and economic conditions which experienced by Iraq which is reflected negatively on communities. So it has to increase the period of courses, according to the ability and knowledge of the trainees involved in these courses.

\section{THE ROLE OF PETRONAS TO DEVELOP THE IRAQI STAFFS}

Under the agreement between the Iraqi Oil Ministry and foreign companies under the licensing and participation [16] contracts that is conducted within the first licensing round in the 30 / June / 2008 as well as the second licensing round in the 13 / December / 2008. It assures that the contracting companies pay an obligatory training fee which is (50) million 
dollars a year to the Iraqi Oil Ministry to develop the local staff which providing employment opportunities and it reflects positively to reduce the unemployment rate [17].

As it is noted by the researcher and the belief in which Petronas relied on (the future development of Iraq's oil in the hands of their own people) the basis of their belief in the importance and the role of human development and building the capacity at various levels and in various conditions, Petronas company has made many courses inside and outside Iraq in order to create high expertise and skills of Iraqi staffs that are able to manage and develop the oil industry in Iraq through a number of things. The Petronas trained 38 trainees in Malaysia after being subjected to more than a year in the development and training phase, where they arrive at their headquarters in Al Garraf oil field on 15/April / 2012, they were engaged on their work according to their competence within the induction program for trainees technicians (POT), after they were introduced to the project and the nature of the work [18].

On 12 / July / 2012,38 Iraqi technician trainees were graduated as the first of trainees as production operators after completing 15 months of intensive training where they took courses to learning the English language and software skills (ESS), and courses in learning petroleum technology programs, in each of the facilities of Petronas in Malaysia [19].

It is also to create a spirit of cooperation and work on the principle of one team and for the success of the oil industry in Iraq, Petronas has trained more than 282 Iraqi technicians belonging to:

1. The Iraqi Ministry of Oil (MoO) totaling 48 trainees.

2. South Oil Company (SOC) totaling 234 trainees [19].

Sessions were held in Malaysia in Petronas Learning Center (PLC) and the Institute of Technology Petronas (INSTEP) and the aim of these courses the number of Iraqi staffs and to achieve mutual cooperation. As well as part of the knowledge working in a practical not theoretical procedure, the Petronas trained 50 Iraqis in Malaysia, the Petronas locations in the city Kerth and it was part of the programme for intensive training to learn the English language and technological information where they were graduated in December 2012 session [20].

On the foregoing and as it is evident for the researcher and through the efforts undertaken by Petronas and its many courses outside Iraq, especially the staffs which work in Al Gharraf oil field and it focuses mainly on teaching and learning on the grounds that the beginning should be in accordance with the true and practical approach and did the application in a realistic way not only theoretical, so the focus was on the process of learning the Iraqis on the experiences and skills of scientific process and they were not found in Iraq resulting in two things:

1. The first thing is to create a number of Iraqi staffs that are capable of managing oil operations in its current and future goals so as to ensure its success and the ability to initiate according to a scientific base that is based on teaching and learning.

2. The second thing is to exit Iraq from isolation for several economic and political reasons, and to keep abreast of developments and global growth in the oil field after isolation and stay away from all forms of development in the field of oil especially that Iraq occupies a privileged position at the global level [21].

\section{THE NEGATIVE ASPECTS OF THE SESSIONS HELD BY PETRONAS}

There are negative aspects as seen by a researcher that must stand by and discussed in order to reach integration in action. The Numbers which participate in the sessions: Through what has been discussed, we note that the numbers that have participated in courses not in a required level, that is, their numbers are a few and they require more numbers either because Al Garraf oil management in terms of duration which extends to 20 years and in terms of production which agreed upon arrives to 230,000 barrel per a day, and this of course needs many staffs.

The Courses type: the courses that held abroad and according to what has been mentioned by Gharraf magazine that is issued by Al Garraf oil field, and issued by the Department of Company Affairs (PCIHPV) which has the official capacity in the publication that the focus intensely was on English language, and this of course is very necessary in order to deal and gain experience from the other through the current language that is understood by the two parties, but of course we want staffs that are capable of managing the Iraqi oil file in terms of production, distribution ,marketing, exploration and oil research, not only staffs that are able to speak English. The sessions should focus on various disciplines which are needed in the Iraqi oil industry.

Participants' type: Al Garraf oil project and the oil industry in Iraq need a large number of staffs and experience. They need efforts and a wide expertise for quite periods of time for the human staffs to be able to manage the oil file correctly. If the focus is only on the low intermediate levels which is good because the project needs staffs that have scientific and intermediate knowledge and experience for the project, but they should not neglect staffs that have bachelor and higher certificates.

Time courses: the process of learning and change especially in the human aspects need time and this time is necessary for the success and achievement of the purpose for which the sessions have been made and most of the courses need more than this time despite the fact that time is necessary to these companies in terms of cost and effort. Since the interest is not only to register in these courses but the amount of change in the acquisition of knowledge. 


\section{THE FIELD STUDY TO DETERMINE THE SOCIAL IMPACT OF PETRONAS ON THE EDUCATIONAL ASPECT}

After reviewing the theoretical framework for the study which prepares the ground for the problem of the study then comes the field side which [22] is the main source of the descriptive data in the absence of records or collection of new data which represents the field work done by the researcher and reached through the questionnaire forms which were distributed to the study area to see the effect the Malaysian oil company Petronas on the educational aspect in the study area.

The sample was selected randomly in which 130 questionnaire forms were distributed to the inhabitants of the areas around the field of oil Al Gharraf of different ages and at different areas, various academic achievement and functional differences in order to get access to the precise and expressive results from the study population .The study collected 110 questionnaire forms and 20 forms were excluded. The question was as indicated by the questionnaire form.

1. What is the role and impact of Al Gharraf center for the positive and vocational education in Al Gharraf field in the region?

The answer was as shown in Table 2 and Chart 1 which shows the percentage ratios and the numbers of participation in the questionnaire form.

Table 2. The percentages and repetition of the impact of Al Gharraf center for vocational education

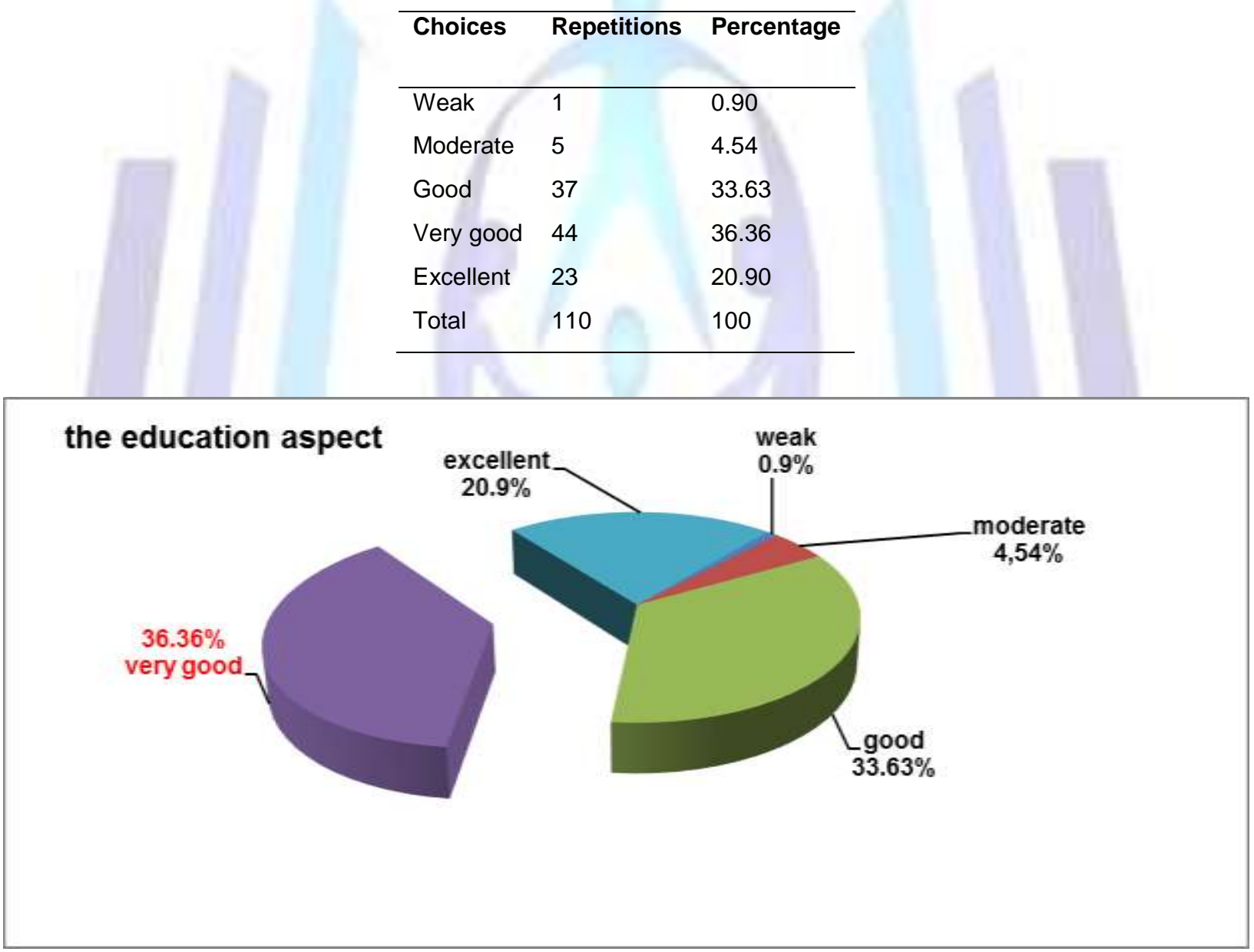

Figure 1 illustrates the positive effect of Al Gharraf Center for Vocational Education

By observing Table 2 and figure No. 1 we note the large social impact that Al Gharraf Center for Vocational Training has on the local community through many things that are undertaken by Petronas and the software program that company has developed to the Institute as it is the operator and financier to the center. It is considered as the best types of vocational education which has the international standards helped greatly to achieve several things for the benefit of local communities, as well as having great potential whether the physical or scientific which helped the company to implement the plans and programs prepared successfully to the center and the visits of the officials and the direct supervision by Petronas to the implementation of plans and programs designed to hasten the implement and achieve goals that the center made for.

2. The education aspect (does Petronas help to the development of education in the region?) 
The answer was as shown in Table 3 and Figure 2 which clarifies the percentage ratios and shows the numbers of participants in the questionnaire form.

Table 3. The percentages and repetition extent of the development of education by Petronas

\begin{tabular}{lll}
\hline Choices & Repetitions & Percentage \\
\hline Weak & 22 & 20 \\
Moderate & 14 & 12.72 \\
Good & 40 & 36.36 \\
Very good & 26 & 32.63 \\
Excellent & 7 & 6.36 \\
Total & 110 & 100 \\
\hline
\end{tabular}

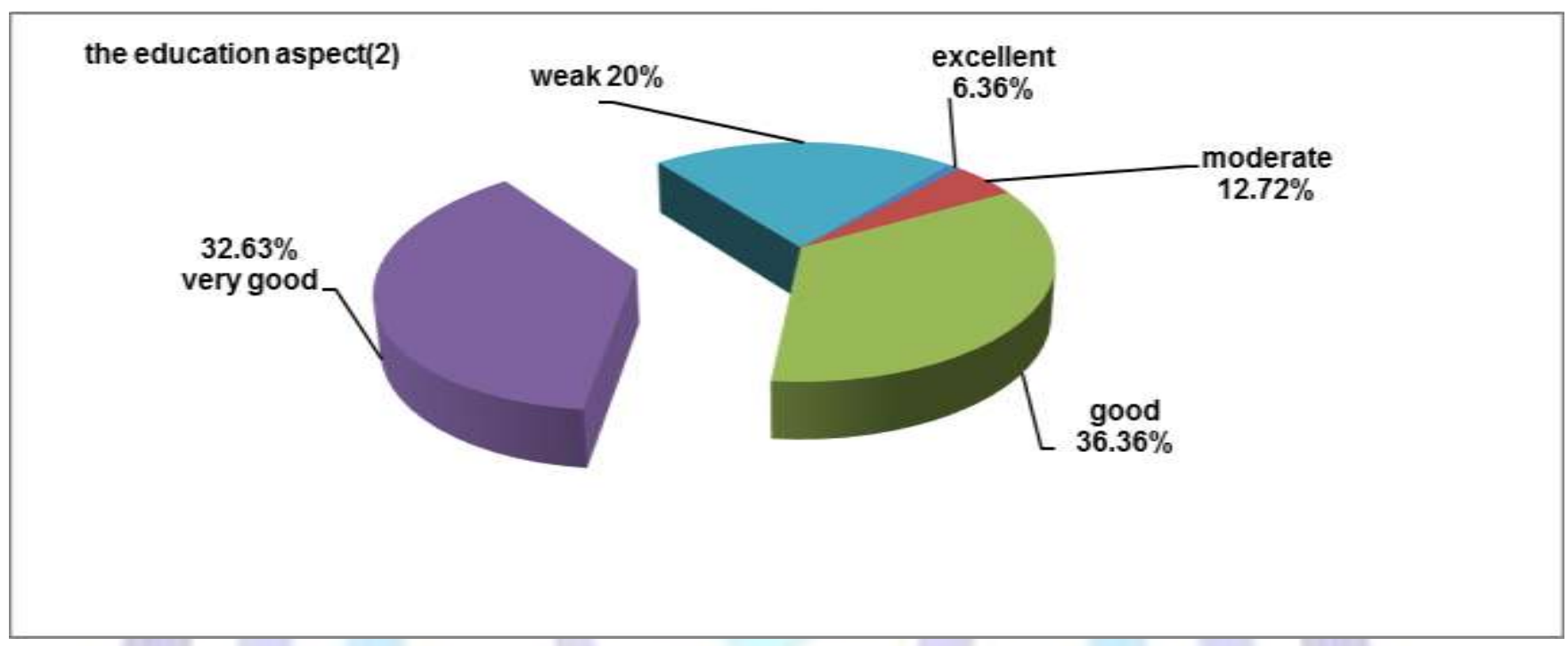

Figure 2 shows the role of Petronas in the development of education in the study area

By observing Table 3 and Graph No. 2 we note that the Petronas company has direct impact to the education sector in Dhiqar in general and the community study in which the company found in particular through a number of things, the most important is the focus on teaching and learning on the grounds that the beginning should be in accordance with the true and practical stems for application so the focus was on the process of Iraqis to learn the experiences and skills of the scientific process that was not found in Iraq that resulting in the creation of numbers of Iraqi staffs that are capable of managing oil operations in its current and future dimensions so as to ensure its success and the ability to initiative according to a scientific base based on education and learning. There are some observations about education in general and Al Garraf center for vocational training in particular including the scientific basis. The center needs to increase in the number of teaching staff and the place where the sessions are held is very small in Al Gharraf center, it does not afford the numbers that the center hopes to offer courses in the present or future. The session's time is short especially if we know that these communities are simple in their ability in education and to acquire skills quickly because they are mostly illiterate and few of them know how to read and write.

\section{CONCLUSION}

The Petronas company has indirectly a direct impact on the educational sector in Dhiqar in general and the community study in which the company found in particular through a number of things, perhaps the most important is the focus on teaching and learning on the grounds that the start should be in accordance with a correct approach that stems from a wide view that is easy for the application so the focus was on the process of Iraqis to learn the experiences and skills of the scientific process that were not found in Iraq resulting in the creation of numbers of Iraqi staffs that are capable of oil operations management of their current and future dimensions so as to ensure its success and the ability to initiate according to a scientific basis that is based on teaching and learning base. The establishment of Al Garraf center for vocational training has a positive impact on local communities through: the help of the local communities located within Al Gharraf oil field so as to ensure the development of their skills, and learning towards the development of skills of individuals to ensure that they are qualified for work within companies and learning towards getting a certain craft and help the start of a special work. The most important observations of the center which needs to be resolved that the center needs teaching staffs and a large place where the sessions are held is small. As well as the time of courses and the quality of the trainees need more time and according to the ability and comprehension of the trainees. Regarding education in general, there are some notes :What is allocated by the budget to the education sector in these communities 
is not enough as well as the areas that are close to Al Gharraf field need the construction of new schools and the purpose is to solve the congestion between school students as well as the lack of communication between the operator and the education administration of Dhiqar, the planning and coordination by the company Petronas as the funds are paid by Petronas but they must be directed by the Petronas company not only the south oil company.

\section{REFERENCES AND INTERVIEWS}

[1] Stinfz, P. 1994. Oil and politics after the Gulf War, translated by Paul Stinfz the first edition in 1994.

[2] Primakov A. 1984. The oil of the Middle East and international monopolies. Bassam Khalil translation. Beirut.

[3] Majeed D. 2005. The revolution of oil prices in 2004, the Office of the university printers Algeria.

[4] Saddam M. 2009. Geo-strategic importance of the oil fields in Kirkuk province, unpublished Master thesis discussed at Baghdad University College of Education, Ibn Rushed.

[5] Ali N. M., 2014. The Gulf War was to a large extent for oil, the opening, the Center for Strategic Studies, University of Karbala, the US special bulletin's number fifth Saturday 25/1/2014.

[6] Hashosh W.H., 2013. Atlas potential of the natural environment of the province of Dhiqar, using geographic information systems (GIS), unpublished Master thesis, the Islamic University in Lebanon, p. 86.

[7] Sabar H. H., 2013. Cartographic representation of the distribution of the population of Dhiqar province in 2010 using GIS, unpublished Master Thesis, University of Dhiqar, p. 138.

[8] Garraf Journal, 2012. Signing ceremony GVTC, Department of Company Affairs, issue1, P6

[9] Garraf Journal, 2012. The official opening of the Institute of Technical Garraf ceremo Department of Company Affairs, issue2, P8.

[10] Sahar M. J., 2014. Interview with Mr. Ma'arj Jassim Sahar, on 09/21/2014. Authorized publication.

[11] Khudair Y., 2014. Interview with the general supervisor of the Center Yas Khudair, dated 09/17/2014. Authorized publication.

[12] Garraf Journal, 2012 Premier Cycle and Information Technology, Department of Company Affairs, issue2, P8

[13] Garraf Journal, 2013 Graduation ceremony Garraf Center, Department of Company Affairs, issue3, P27.

[14] Garraf Journal, 2013. Graduation ceremony Garraf Center, Department of Company Affairs, issue4, P17.

[15] Nasser S., 2014. Interview with Mr. Assistant General Supervisor Mr. Salah Nasser. Dated 09/23/2014. Authorized publication.

[16] Hadi M. A., 2012. Foreign direct investment and its role in the development of Iraq's oil sector, Journal of Management and Economics, No. 91. p. 56.

[17] Muslim H. S. The importance of foreign direct investment in the oil industry Iraqi Petroleum Industries Development 2003-2010, Journal of Economic Sciences, Volume 18, Issue 69, p. 216.

[18] Garraf Journal, 2012. Induction program POT, Department of Company Affairs, issue1, P4.

[19] Garraf Journal, 2012. Graduation ceremony (pot), Department of Company Affairs, issue2, P7.

[20] Garraf Journal, 2013. Training courses, Department of Company Affairs, issue3, P17

[21] Omran, H. A., 2014. Interview with Mr. Hamoud Abbas Omran, the public relations of Petronas Company, dated 09/24/2014. Authorized publication.

[22] Ashour A., 2013. The geographical and technology bases, fifth edition, p. 59. 